\title{
PSYCHOLOGICAL AND PEDAGOGICAL FOUNDATIONS OF PREVENTIVE WORK IN EDUCATIONAL INSTITUTIONS
}

\author{
FUNDAMENTOS PSICOLÓGICOS E PEDAGÓGICOS DO TRABALHO PREVENTIVO \\ EM INSTITUIÇÕES DE EDUCAÇÃO
}

\author{
FUNDAMENTOS PSICOLÓGICOS Y PEDAGÓGICOS DEL TRABAJO PREVENTIVO \\ EN LAS INSTITUCIONES EDUCATIVAS
}

\author{
Tatiana Alekseevna BEZUSOVA ${ }^{1}$ \\ Elena Viktorovna VATINA ${ }^{2}$ \\ Galina Valentinovna NARYKOVA ${ }^{3}$ \\ Natalia Vladimirovna MALTSEVA ${ }^{4}$ \\ Olga Anatolievna PETROVA
}

\begin{abstract}
Theoretical analysis was used in this article to define the concepts of a teenager's social deviation prevention and the degree of elaboration of the issue in question in the literature. Via modeling, the authors described sections of the psychological and pedagogical foundations of preventive work at school. Mathematical methods were used for processing and presenting the course fragment introduction results. General logical methods were applied for the work text design, conclusion formulation. Future teachers' readiness for preventive work is characterized; the theory key points and methods of prevention of social deviations at schools are presented; the developed content introduction into work with students receiving pedagogical education with two educational profiles (majoring in "Primary Education and Life Safety", based on material from the pedagogy course) is described; methodological recommendations for teaching the course are highlighted.
\end{abstract}

KEYWORDS: Teacher education. Deviation. Adolescents.

RESUMO: A análise teórica foi utilizada neste artigo para definir os conceitos de prevenção do desvio social do adolescente e o grau de elaboração do tema em questão na literatura. Por meio de modelagem, os autores descreveram seções dos fundamentos psicológicos e pedagógicos do trabalho preventivo na escola. Métodos matemáticos foram usados para

${ }^{1}$ Perm State University (PSU), Perm - Russia. Associate Professor, Head of the Department of Pedagogy and Psychology. Candidate of Pedagogical Sciences. ORCID: https://orcid.org/0000-0001-8128-9122. E-mail: bezusovatatiana@mail.ru

${ }^{2}$ Perm State University (PSU), Perm - Russia. Associate Professor of the Department of Pedagogy and Psychology. Candidate of Pedagogical Sciences. ORCID: https://orcid.org/0000-0002-7263-2782. E-mail: vatinael@yandex.ru

${ }^{3}$ Perm State University (PSU), Perm - Russia. Associate Professor of the Department of Pedagogy and Psychology. Candidate of Pedagogical Sciences. ORCID: https://orcid.org/0000-0003-2983-8643. E-mail: gnarykova@internet.ru

${ }^{4}$ Perm State University (PSU), Perm - Russia. Associate Professor of the Department of Pedagogy and Psychology. Candidate of Psychological Sciences. ORCID: https://orcid.org/0000-0002-7780-8847. E-mail: natalia maltseva@inbox.ru

${ }^{5}$ Perm State University (PSU), Perm - Russia. Senior Lecturer of the Department of Pedagogy and Psychology. ORCID: https://orcid.org/0000-0001-6032-7628. E-mail: olga.an.petrova@yandex.ru 
processar e apresentar os resultados da introdução do fragmento do curso. Métodos lógicos gerais foram aplicados para o desenho do texto de trabalho e formulação da conclusão. A prontidão dos futuros professores para o trabalho preventivo é caracterizada; são apresentados os pontos-chave da teoria e métodos de prevenção dos desvios sociais nas escolas; é descrita a introdução do conteúdo desenvolvido no trabalho com alunos que recebem formação pedagógica com dois perfis educacionais (com especialização em "Educação Básica e Segurança de Vida", com base no material do curso de pedagogia); recomendações metodológicas para o ensino do curso são destacadas.

PALAVRAS-CHAVE: Formação de professores. Desvio. Adolescentes.

RESUMEN: En este artículo se utilizó el análisis teórico para definir los conceptos de prevención de la desviación social del adolescente y el grado de elaboración del tema en cuestión en la literatura. Mediante la modelización, los autores describieron secciones de los fundamentos psicológicos y pedagógicos del trabajo preventivo en la escuela. Se utilizaron métodos matemáticos para procesar y presentar los resultados de la introducción de los fragmentos del curso. Se aplicaron métodos lógicos generales para el diseño del texto de trabajo, la formulación de la conclusión. Se caracteriza la preparación de los futuros profesores para el trabajo preventivo; se presentan los puntos clave de la teoría y los métodos de prevención de las desviaciones sociales en las escuelas; se describe la introducción del contenido desarrollado en el trabajo con los estudiantes que reciben educación pedagógica con dos perfiles educativos (que se especializan en "Educación Primaria y Seguridad de la Vida", basado en el material del curso de pedagogía); se destacan las recomendaciones metodológicas para la enseñanza del curso.

PALABRAS CLAVE: Formación del profesorado. Desviación. Adolescentes.

\section{Introduction}

There is a steady increase in aggressive behavior, indifference, cruelty, alcoholism, drug addiction, and delinquency of schoolchildren worldwide. It is necessary to state the frequent cases of extremism among schoolchildren. During the first two months of the 2021-2022 academic years, there were two cases of armed students entering the territory of an educational institution in the Perm Region only. In one of them, about 40 students were injured. It is difficult to overestimate the social significance of the problem of deviant behavior of students. Due to their social characteristics and acute perception of the environment, teenagers are part of society in which the accumulation and realization of negative protest potential occur most quickly.

Today, the school is a social institution with great potential, capable of countering the spread of extremism and terrorism among children through educational work to develop spiritual and moral values. There is an obvious need to increase teachers' awareness of all directions to prevent taking toxic substances and/or drugs, extremism, terrorism, etc., in the 
teenage environment. The problem we face today is the lack of teachers' knowledge and skills to face children.

Contradiction: there is no discipline in the curricula of university students in pedagogical areas, the content of which is aimed at psychological and pedagogical preparation for the organization of preventive work at school. At the same time, there are opponents of the need for such a course, who are guided by the idea that social educators and psychologists should deal with issues of preventive work. We have to state that only two specialists cannot cover the entire scope of preventive work. As a rule, a significant amount of their labor functions is directed to the diagnostic component. Two ways of solving the problem can be traced: the organization of a commission on psychological and pedagogical assistance (a sample of teachers and the administration of an educational organization) or to equip each person with pedagogical education with a set of competencies related to preventive activities.

\section{Literature review}

The concept of prevention is closely related to the concept of deviation. It is the elimination and prevention of various kinds of social deviations that preventive work is aimed at. According to Kulganov and Kuzmicheva (2009), The main causes of deviant behavior in adolescents are violation of family structure and function; psychoemotional overload and domestic unrest; lack of spirituality, violence, and sex propagated by the media; advertising of tobacco products and alcoholic beverages; school factors (lack of individual approach, inadequate educational measures, etc.). Chvyakin, Kozilova and Ratova (2016) attribute aggressive behavior to typical adolescent deviation, in preference to using violent means to achieve goals. Note that a typical teenage deviation may well become a prototype of extremist manifestations in the future.

A detailed analysis of the common types and forms of deviant behavior in adolescence is carried out in the manual of Tinuntseva (2013). The manual examines the essential characteristics, causes, and prerequisites of adolescence's theft, vagrancy, and aggressiveness.

Alvarez and Diaz (2019) describe purposeful work on forming current values among adolescents. They offer a series of educational seminars for the formation of spiritual and moral values among students. Borovskaya and Semjannikov (2018) studied the features of adolescents' spiritual and moral development, considering the specifics of their worldview. Their research defines modern psychological and pedagogical interaction approaches with adolescents based on a spiritually oriented dialogue of the Orthodox Russian psychologist 
Doctor of Psychological Sciences Tamara Florenskaya. Borovskaya and Semjannikov (2018) declare literature as an effective means of forming the values of a teenager. [...] "Literature with high moral content shapes the teenager's style of speech, thinking, affects the way of life, leads through repentance to the transformation. The spiritually oriented dialogue with teenagers [...] makes prevention of deviations possible" (BOROVSKAYA; SEMJANNIKOV, 2018, p. 977).

In the scientific work by Khodarahimi (2013), the aim was to study the relationship between impulsivity, aggression, and signs of psychopathic deviations. The authors' attention was also directed to studying the role of age and gender in the studied phenomena. The study was conducted on a sample of 146 teenagers from Iran. According to the study results, a significant correlation was found between the indicators of impulsivity and psychopathy. At the same time, the gender composition of the subjects was insignificant.

Obolenskaya et al. (2018) conduct an in-depth analysis of the concept of cybervandalism (hacking other people's pages, Internet harassment) and study its features in the adolescent environment. The spread of vandalism is associated with the great involvement of the younger generation in social networks. Conducting the study, the authors conclude that the subjects have no negative perception of vandalism in the network. Hacking other people's pages and cyberbullying are not a big evil for children and are becoming commonplaces. The consequences for the victims and the participants themselves pose a danger to minors' socialization, mental and physical health. The psyche of teenagers is not ready for the perception of large volumes of available and harmful information. Teenagers are increasingly trying to find a way out of the accumulated aggression in social networks. Classmates bully teenagers, who often become victims of cyberbullying.

The influence of cyberspace on children's deviation is considered in Kalinina et al. (2018). Their article is devoted to the problem of the protection of children and adolescents in the modern formation society. They analyzed psychological and pedagogical security factors and approaches to preventing Internet risks and threats to life. One of the conditions for successful preventive work in an educational institution, in their opinion, is the involvement of children, teachers, and parents in joint research activities to study Internet risks and threats to life.

Kryshtanovych et al. (2020) describe the features of moral education on the personality of adolescents. The process of forming moral judgments regarding its dynamics from the preconventional to the postconventional level of development in adolescents with illegal behavior is considered. Slavova and Chvyakin (2019) examined 60 adolescents with aggressive 
antisocial behavior aged 14 to 17 years. The subjects were divided into two age groups: the first group was 14-15 years old, the second was 16-17 years old. The residence factor of subjects (residents of Moscow and those from different regions of the Russian Federation) was considered. Application of the L. Kolberg's method revealed the features of the moral consciousness of the subjects. The study's conclusion is the data on the degree of development of moral judgments of adolescents with critical social deviations. Information was obtained on the age definition of moral development, depending on the region of residence of the subject.

Kondrat'ev (1997) devoted a research article to the behavioral deviations of adolescents, where he speaks about the importance of preventive work with them. The author is particularly concerned about the imbalance of time spent communicating with peers and educational and professional activities.

The issues of combating terrorism and extremism in an educational institution are covered by Eliseev, Vicentiy and Gluchich (2017). They propose new early warning methods of extremism among young people. In contrast to approaches that focus on complex statistical methods of analyzing committed crimes of an extremist nature, the authors propose an early diagnosis of extremist manifestations among young people.

Within the scope of our research, the position of Babenko, Kuzmina and Yusupova (2016) is of particular interest. Following their views, teaching preventive work to students of pedagogical universities is relevant and significant. Future teachers should take care not only of the work to combat drug addiction and alcoholism of students, but also dwell on possible solutions to radical ideas that can penetrate the minds. The article describes methods of preventive work with extremism and terrorism in English lessons. Interesting are such techniques as informative excursions to places of terrorist attacks and museums with a story about people who died in wars provoked by someone's radicalism.

Bull and Rane (2019) argue that social marginalization contributes to the creation of conditions for radicalization. They describe the negative impact of stereotypes about young Muslims on the connection of religion with radicalization and terrorism. The authors conclude that such activities can increase the sense of marginalization even among those who are well integrated into the Australian society.

Neverkovich et al. (2018) analyzed the problem of Internet addiction among students (14-19 years old) from the point of view of the social health of the individual and society as a whole. The authors identified Internet addiction as a complex phenomenon in a pilot study involving more than 600 adolescents aged 14-19 years (students of secondary schools, colleges, and universities). The prerequisites for its development determine and distinguish its gradual 
formation in students (light infatuation, passion, dependence, attachment). At the ascertaining stage of the experiment, a screening study was conducted to study the state of Internet addiction among young students in social networks. The results showed the need to develop and implement programs to prevent Internet addiction among students.

\section{Materials and methods}

From our position, it is necessary to include a course in the curricula for future teachers, which will teach them the basics of preventive work in an educational institution. When designing the educational course, we were guided by the model described in Figure 1. As the working title of the course, we propose the following: "Psychological and pedagogical foundations of preventive work at school", but you can also borrow the name from the field of social pedagogy and call the course "Theory and methodology of prevention of social deviations at school". This model is based on structural scheme of categories systems describing education (KASATKINA; RUDNEVA, 2015).

Figure 1 - The model of the course is the psychological and pedagogical foundations of preventive work at school

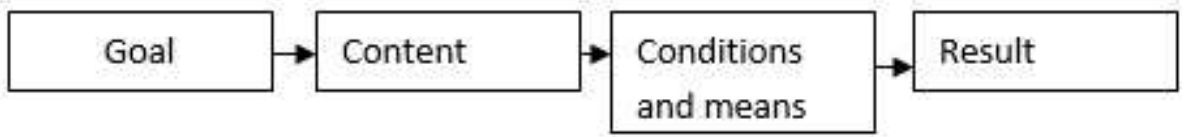

Source: Prepared by the authors

The course is designed for at least three credits ( 1 unit equals to 36 hours) and includes 14 lectures and 28 practical classes. At the same time, the prevention of juvenile delinquency is considered a system of social, legal, pedagogical, and other measures to identify and eliminate the causes and conditions that contribute to offenses and antisocial actions of minors (ALZHEV, 2019).

The purpose of the course: to form in future teachers the need for sociopedagogical and psychological knowledge, the desire to use them in life and work, in the interests of their development, to create conditions for the full psychological development of the child at each age stage, to timely prevent possible violations in the formation of personality and intelligence.

Let us characterize the content of the course modules.

Module 1. Theoretical foundations of deviant behavior. The content of this module reveals the definition of the term behavior, the main characteristics of human behavior. Students are acquainted with the criteria of deviant behavior and the main types of social deviations. 
Antisocial (delinquent), antisocial (immoral), and autodestructive (self-destructive) behaviors are introduced into consideration (ZMANOVSKAYA, 2003).

Module 2. Sociopedagogical technologies of working with children at risk of a socially dangerous situation in school conditions. The work system on preventing offenses and recidivism among minors arises and develops primarily where there is direct interaction with children and their problems. That is why it is fundamentally important to analyze various forms and ways of helping children find and justify the system of specialists providing preventive activities among juvenile offenders. The content of the module is required to equip students with knowledge of regulatory and legal documentation (Laws "On the basics of social services for the population", "On the basics of the system of prevention of neglect and delinquency", and "On the basic guarantees of the rights of the child in the Russian Federation"). Within the framework of this section, it is necessary to conduct a seminar-practical lesson dedicated to explaining the Law "On the basics of the system of prevention of neglect and offenses", which defines the basic principles of preventive activities with different categories of children (neglected, homeless, in a socially dangerous situation).

Module 3. The role and importance of the school in the prevention of offenses or recidivism among minors. Teachers of the school team can identify children at risk promptly, determine the social situation of the child's development, risk factors in their environment and development, the child's resources (internal and external), develop and implement individual support programs. Practice shows that a psychologist and a social pedagogue should carry out the initial examination. A psychologist collects psychological information about a child, and a social pedagogue collects data about the family and the immediate environment of a child at risk. It is important to build a working system on preventing offenses among adolescents, implementing which subject teachers, additional education specialists, high-school volunteers, and the parent community should participate. In practical classes, students are acquainted with techniques that help to track and record offenses that manifest themselves in various forms of deviant, delinquent and criminal behavior, and identify the degree of child's maladaptation.

Module 4. Methods of drug addiction prevention in adolescents. Prevention of addiction to drugs and other psychoactive substances can be primary, secondary, and tertiary. Each type of prevention is studied from the perspective of sociopedagogical, psychological, and medical technologies. Students should be introduced to various prevention strategies for each level.

Module 5. Prevention of involvement of adolescents in antisocial and antisocial adolescent groups. Prevention of extremism and terrorism. Informal groupings are extremely closed to adults, especially teachers. Therefore, only indirect influence is possible. The strategy 
is based on adults showing sincere, genuine interest in where the child lives and breathes, in what principles its communication in this or that grouping is based on, what value they get by participating in such associations. The absence of condemnation and explicit criticism from an adult helps to remove barriers to communication, makes children more open.

The organization of preventive work with students of educational organizations is the stage following the sociopsychological testing (ANDREEVA et al., 2011). When determining methods of preventive activity, preference should be given to a combination of individual and group methods of work, as well as methods of direct and indirect influence, development and disclosure of mental and personal resources, support for a young person, and help in the selfrealization of own life purpose.

The goals of prevention include (ANDREEVA et al., 2011):

- Creating conditions for maintaining the need for a healthy lifestyle.

- Providing conditions for forming socially supportive behavior, in which children get the opportunity to talk about what worries them, and are accustomed to helping their loved ones - developing a safe and accessible system of assistance them.

- Formation of knowledge in the field of countering the intake of alcohol, psychoactive substances, etc.

- Formation of motivation to change maladaptive behaviors. Such work is carried out with representatives of risk groups or people with already formed addiction and their family members.

The existing approaches to classification of preventions are presented in Table 1.

Table 1 - Prevention levels; types of preventions

\begin{tabular}{|l|l|l|}
\hline Type of prevention (by target group) & $\begin{array}{l}\text { Type of prevention (according to the content of } \\
\text { the activity) }\end{array}$ & $\begin{array}{c}\text { Prevention } \\
\text { level }\end{array}$ \\
\hline $\begin{array}{l}\text { Primary prevention is a set of measures } \\
\text { to prevent involvement }\end{array}$ & $\begin{array}{l}\text { Specific prevention specialized information } \\
\text { campaigns in mass media, lessons, psychological } \\
\text { training, or thematic classes for teenagers }\end{array}$ & Personal \\
$\begin{array}{l}\text { Secondary prevention is a set of } \\
\text { preventive measures against the } \\
\text { development of diseases and } \\
\text { complications }\end{array}$ & $\begin{array}{l}\text { General social prevention (alternative to } \\
\text { involvement in the dependent is created behavior } \\
\text { organized by teenagers in their free time) }\end{array}$ & Family \\
\hline
\end{tabular}


Tertiary prevention or rehabilitation is a set of measures aimed at preventing breakdowns and relapses of the disease

Source: Prepared by the authors

Table 1 is composed according to collection of methodological materials on the organization of preventive work based on the results of sociopsychological testing conducted in all educational institutions of the Russian Federation (SHVEDCHIKOVA; BIKTAGIROVA, 2020).

The educational course is interdisciplinary. The material must be selected so that students can start studying the content without special sociopedagogical training. Several teachers supervising pedagogical and psychological disciplines can be involved in conducting lectures.

A fragment of the course was introduced in the discipline "pedagogy" during one trimester. The associate professor T. A. Bezusova, a leading teacher, carried out the work on the implementation. The criteria for the effectiveness of the materials used were the formation of the characteristics of readiness for preventive work in students, i.e., the ability to plan the preventive work of (i) drug addiction; (ii) destructive behavior; (iii) involving adolescents in antisocial groups; (iv) of delinquent (illegal) behavior of adolescents.

The results were summarized in October 2021. Students were offered a test of 16 tasks, and 4 test tasks were assigned to evaluate each skill. The number of students in the group is 11 people. The scores for the first four skills were summed up for each student (Figure 2). According to the number of points scored, the students were divided into three levels:

- High - scored from 14 to 16 points;

- Average - scored from 9 to 13 points;

- Low - less than 9 points scored. 
Figure 2 - Distribution of students of the pedagogical education direction (Primary education and life safety orientation) according to the levels of formation of readiness for preventive work at school

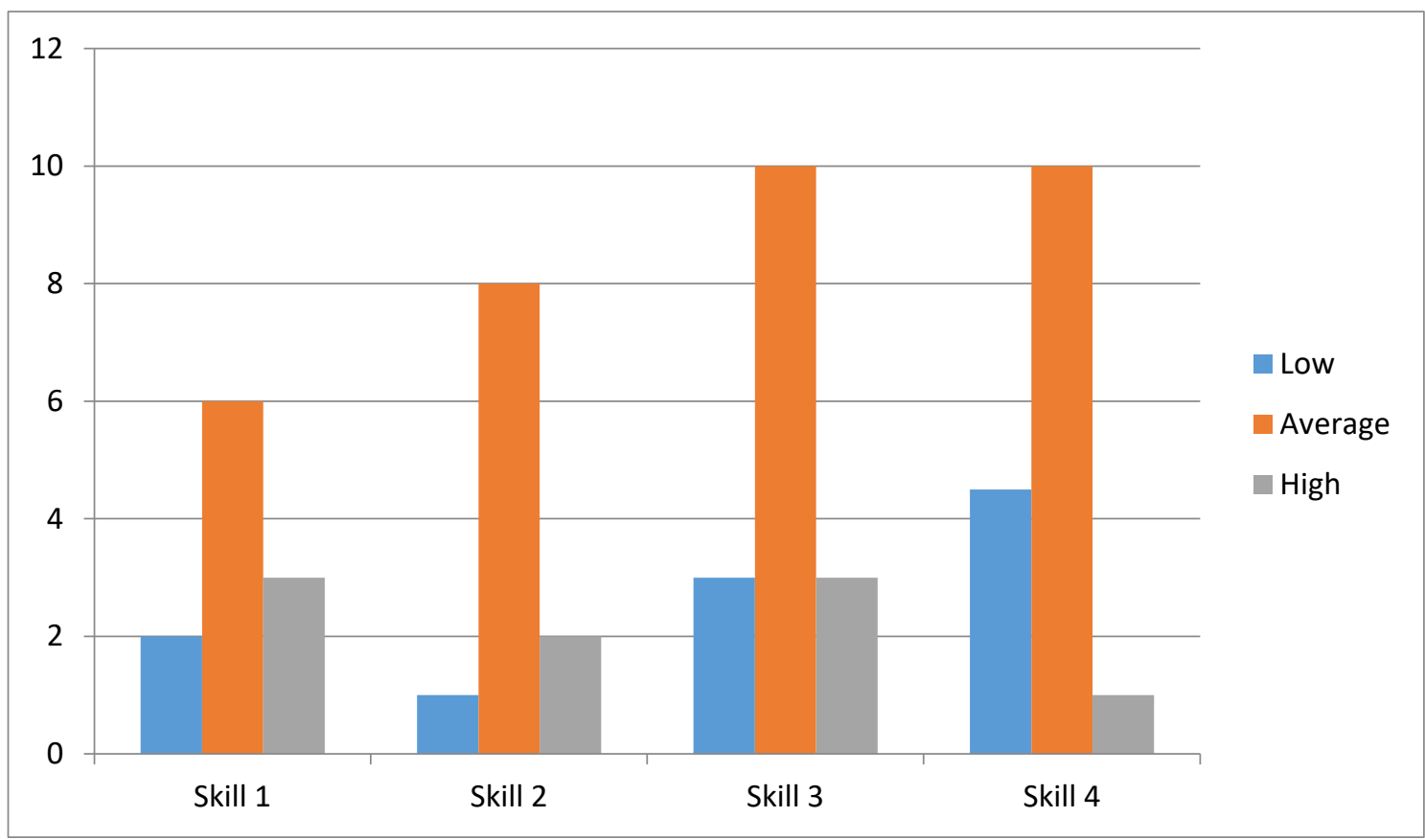

Source: Prepared by the authors

The presented results conclude that the students demonstrated an average level of readiness for preventive work. The low indicators are explained by the fact that only part of the course was studied with the students, namely 8 hours of lectures and 12 hours of practical classes. The expediency of such a pilot experiment is explained by the fact that we assess the readiness of student teachers to receive the prepared content.

As part of the experiment, students were able to analyze the situation of offenses and crimes among students of the municipal educational institution "Gymnasium No. 1" in Solikamsk (see Table 2).

Table 2 - Analysis of the situation of offenses and crimes among students

\begin{tabular}{|c|c|c|c|c|c|c|c|c|}
\hline \multirow[t]{4}{*}{ 1. Forms of deviant behavior } & \multicolumn{8}{|c|}{$\begin{array}{c}\text { Degree of severity (from } 1 \text { to 5) } \\
1 \text { - Practically does not occur } \\
2 \text { - Occurs, but very rarely } \\
3 \text { - Sometimes occurs } \\
4 \text { - Occurs frequently } \\
5 \text { - Very characteristic of this group }\end{array}$} \\
\hline & \multicolumn{4}{|c|}{ 2019-2020 } & \multicolumn{4}{|c|}{$2020-2021$} \\
\hline & \multicolumn{4}{|c|}{ classes } & \multicolumn{4}{|c|}{ classes } \\
\hline & $1-4$ & $5-9$ & $10-11$ & school & $1-4$ & 5-9 & $10-11$ & school \\
\hline
\end{tabular}




\begin{tabular}{|c|c|c|c|c|c|c|c|c|}
\hline $\begin{array}{l}\text { 1.1. Violation of the rules of behavior } \\
\text { at school (disruptions of lessons, } \\
\text { absenteeism, refusal to complete } \\
\text { tasks) }\end{array}$ & 2 & 4 & 1 & 8 & 1 & 5 & 1 & 7 \\
\hline 1.2. Rudeness, ribaldry & 1 & 4 & 1 & 6 & 1 & 4 & 1 & 7 \\
\hline 1.3. Smoking & 1 & 3 & 2 & 6 & 2 & 4 & 2 & 8 \\
\hline $\begin{array}{l}\text { 1.4. Early onset of sexual activity } \\
\text { (before } 16 \text { years) }\end{array}$ & 1 & 4 & 4 & 9 & 1 & 4 & 4 & 9 \\
\hline $\begin{array}{l}\text { 1.5. Insubordination, criticism of } \\
\text { adults }\end{array}$ & 2 & 5 & 3 & 10 & 2 & 4 & 4 & 10 \\
\hline 1.6. Negative attitude to education & 1 & 5 & 2 & 10 & 3 & 5 & 3 & 11 \\
\hline $\begin{array}{l}\text { 1.7. Humiliating others (by words or } \\
\text { actions) }\end{array}$ & 2 & 4 & 1 & 7 & 1 & 5 & 2 & 8 \\
\hline 1.8. Drinking beer & 1 & 4 & 2 & 7 & 1 & 5 & 2 & 8 \\
\hline 1.9. Begging & 1 & 2 & 1 & 4 & 1 & 3 & 1 & 5 \\
\hline $\begin{array}{l}\text { 1.10. Wearing provocative clothes, } \\
\text { hair styles }\end{array}$ & 1 & 5 & 4 & 10 & 1 & 5 & 3 & 9 \\
\hline \multirow{4}{*}{ 2. Forms of delinquent behavior } & \multicolumn{8}{|c|}{ Number of cases } \\
\hline & \multicolumn{4}{|c|}{ 2019-2020 } & \multicolumn{4}{|c|}{$2020-2021$} \\
\hline & \multicolumn{4}{|c|}{ classes } & \multicolumn{4}{|c|}{ classes } \\
\hline & $1-4$ & $5-9$ & 10-11 & school & $1-4$ & 5-9 & 10-11 & school \\
\hline 2.2.1. Escapes from home & 2 & 5 & 1 & 8 & 1 & 6 & 0 & 7 \\
\hline $\begin{array}{l}\text { 2.2. Consumption of alcoholic } \\
\text { beverages }\end{array}$ & 2 & 15 & 7 & 24 & 3 & 20 & 8 & 31 \\
\hline $\begin{array}{l}\text { 2.3. The use of toxic substances } \\
\text { (tablets, household chemicals) }\end{array}$ & 0 & 1 & 0 & 0 & 0 & 5 & 0 & 5 \\
\hline 2.4. Vehicle theft & 0 & 1 & 0 & 1 & 0 & 0 & 0 & 0 \\
\hline 2.5. Petty theft & 3 & 7 & 0 & 10 & 5 & 8 & 9 & 22 \\
\hline 2.6. Fights, infliction of bodily harm & 5 & 12 & 1 & 18 & 7 & 5 & 0 & 12 \\
\hline 2.7. Fraud & 0 & 0 & 0 & 0 & 0 & 0 & 0 & 0 \\
\hline 2.8. Use of narcotic substances & 0 & 0 & 0 & 0 & 0 & 0 & 0 & 0 \\
\hline \multirow{4}{*}{ 3. Forms of criminal behavior } & \multicolumn{8}{|c|}{ Number of cases } \\
\hline & \multicolumn{4}{|c|}{ 2019-2020 } & \multicolumn{4}{|c|}{$2020-2021$} \\
\hline & \multicolumn{4}{|c|}{ classes } & \multicolumn{4}{|c|}{ classes } \\
\hline & $1-4$ & $5-9$ & 10-11 & school & $1-4$ & 5-9 & 10-11 & school \\
\hline $\begin{array}{l}\text { 3.1. Participation in an organized } \\
\text { racket }\end{array}$ & 0 & 0 & 0 & 0 & 0 & 0 & 0 & 0 \\
\hline 3.2. Major thefts & 0 & 0 & 0 & 0 & 0 & 0 & 0 & 0 \\
\hline 3.3. Robberies & 0 & 0 & 0 & 0 & 0 & 0 & 0 & 0 \\
\hline
\end{tabular}




\begin{tabular}{|l|c|c|c|c|c|c|c|c|}
\hline 3.4. Rape & 0 & 1 & 0 & 0 & 0 & 0 & 0 & 0 \\
\hline $\begin{array}{l}\text { 3.5. Distribution of narcotic } \\
\text { substances }\end{array}$ & 0 & 0 & 0 & 0 & 0 & 0 & 0 & 0 \\
\hline $\begin{array}{l}\text { 3.6. Cases of malicious hooliganism } \\
\text { with significant damage }\end{array}$ & 0 & 0 & 0 & 0 & 0 & 0 & 0 & 0 \\
\hline
\end{tabular}

Source: Adapted from Zmanovskaya (2003).

According to Table 2, we conclude that quantitative indicators of deviant and delinquent behavior forms are most often found when calculating $t_{\mathrm{emf}}=0.6$ at $t_{\mathrm{cr}}=2.1(\mathrm{p} \leq 0.05)$ for the form of deviant behavior and $t_{\mathrm{emf}}=0.4$ at $t_{\mathrm{cr}}=2.14(\mathrm{p} \leq 0.05)$ for the form of delinquent behavior, they are in the zone of unavailability.

\section{Results}

Based on the positions discussed above, preventive work is understood as a system of social, pedagogical, aimed at identifying and eliminating the causes and conditions that contribute to the antisocial actions of minors. In our study, we conducted a pilot experiment in which we showed the effectiveness of introducing it in to the curriculum of future teachers, regardless of the educational profile. This course involves arming students with psychological and pedagogical fundamentals of preventive work in an educational institution.

As the characteristics of readiness for preventive work, we choose the ability to plan the preventive work of: drug addiction; destructive behavior; involving adolescents in antisocial and antisocial adolescent groups; and of delinquent (illegal) behavior of adolescents.

Future teachers should be prepared to increase the effectiveness of the child's behavioral strategies; create conditions for the development of empathy, internal control among students; be sensitive and ready to come to the rescue, respond promptly to the changes taking place with the child. Specially trained psychologists should carry out the tasks of primary prevention with educators and medical and social psychologists.

\section{Discussion}

A study was conducted on selecting content for the course "Psychological and pedagogical foundations of preventive work" relevant for students of pedagogical directions. An experiment was conducted to assess the number of adolescents with social deviations in the 
Municipal Autonomous Educational Institution Gymnasium No. 1. A cross-section of future teachers was carried out to determine their readiness to carry out preventive work.

Of course, there are opponents of introducing such a course into the curriculum of future teachers. However, the study proves the importance, relevance, and significance of the considered content for the teacher. Only the systematic work of the sociopsychological service and each teacher individually will allow us to fully protect the interests of children and eliminate the causes of the manifestation of various forms of deviant behavior in children, as well as delinquent and criminal behavior.

\section{Conclusion}

The proposed article defines and characterizes preventive work at school and summarizes the educational course that reveals preventive work's psychological and pedagogical foundations with future teachers. The results of the introduction of a fragment of the course in to the educational content of students in the direction of pedagogical education with two educational profiles (Primary orientation education and life safety) (based on the material of the subject "pedagogy") are described. Because the paper presents a draft educational course and the authors did not set the goal of strictly scientific proof of its effectiveness with control and experimental groups, only one group for October 2021 is presented. Nevertheless, the results allow us to speak about the effectiveness of the work carried out.

Thus, the purpose of the study has been achieved. As a continuation of the work, a strict pedagogical experiment can be carried out.

\section{REFERENCES}

ALVAREZ, Y. P.; DIAZ, Y. C. Formation of values in adolescents with affective behavior deviations. Avances, Pinar del Río, v. 21, n. 3, p. 344-355, 2019. Available: http://www.ciget.pinar.cu/ojs/index.php/publicaciones/article/view/453. Access: 8 Dec. 2021.

ALZHEV, D. V. Social'naja pedagogika: konspekt lekcij [Social pedagogy: A textbook]. 2. ed. Saratov: Scientific Book, 2019.

ANDREEVA, O. I. et al. Profilaktika i razrešenie social'nyh konfliktov [Prevention and resolution of social conflicts]. St. Petersburg: St. Petersburg State Institute of Psychology and Social Work, 2011. 
BABENKO, O.; KUZMINA, O.; YUSUPOVA, L. Extremism prevention at English classes with students. In: INTERNATIONAL TECHNOLOGY, EDUCATION AND DEVELOPMENT CONFERENCE, 10., 2016, Valencia. Proceedings [...]. Valencia: IATED, 2016. p. 4275-4286. DOI: https://doi.org/10.21125/inted.2016.2062

BOROVSKAYA, H.; SEMJANNIKOV, S. The word as a means of preventing adolescents' deviations. In: INTERNATIONAL FORUM ON TEACHER EDUCATION, 4., 2018, Kazan. Proceedings [...]. Detroit: The European Proceedings of Social and Behavioural Sciences, 2018. p. 977-985. DOI: https://doi.org/10.15405/epsbs.2018.09.114

BULL, M.; RANE, H. Beyond faith: Social marginalisation and the prevention of radicalisation among young Muslim Australians. Critical Studies on Terrorism, London, v. 12, n. 2, p. 273-297, 2019. DOI: https://doi.org/10.1080/17539153.2018.1496781

CHVYAKIN, V. A.; KOZILOVA, L. V.; RATOVA, I. V. Patterny agressivnogo povedenija deviantnyh podrostkov kak ob"ekt pedagogičeskogo issledovanija problem obŝestvennoj bezopasnosti [Patterns of aggressive behavior of deviant adolescents as an object of pedagogical research of public safety problems]. Pravo. Èkonomika. Bezopasnost' ${ }^{\prime}$ Law. Economy. Safety], Moscow, v. 3, n. 9, p. 129-135, 2016.

ELISEEV, S.; VICENTIY, I.; GLUCHICH, V. Youth political extremism: Methods of early warning. Teorija in Praksa, Ljubljana, v. 54, n. 6, p. 990-1111, 2017. Available: https://www.fdv.uni-lj.si/docs/default-source/tip/politični-ekstremizem-med-mladimi-metodezgodnjega-opozarjanja.pdf. Access: 9 Dec. 2021.

KALININA, N. V. et al. Psychological And Pedagogical Resources Of Security Provision And Prevention Of Internet Risks And Life Threats Among Children And Teenagers In The Educational Environment. Modern Journal of Language Teaching Methods, Istanbul, v. 8, n. 8, p. 118-129, 2018. DOI: https://doi.org/10.26655/mjltm.2018.8.1

KASATKINA, N. E.; RUDNEVA E. L. Pedagogika: kurs lekcij [Pedagogics: Course of lectures]. 3. ed. Kemerovo: Kemerovo State University, 2015.

KHODARAHIMI, S. Impulsivity, Aggression, and Psychopathic Deviation in a Sample of Iranian Adolescents and Young Adults: Gender Differences and Predictors. Journal of Forensic Psychology Practice, Philadelphia, v. 13, n. 5, p. 373-388, 2013. DOI: https://doi.org/10.1080/15228932.2013.829733

KONDRAT'EV, M. Y. Tipologičeskie osobennosti psihosocial'nogo razvitija podrostkov [Typical deviations in adolescents' psychosocial development]. Voprosy Psychologii [Questions of Psychology], Moscow, v. II, n. 3, p. 69-78, 1997. Available: http://www.voppsy.ru/journals_all/issues/1997/973/973069.htm. Access: 7 Dec. 2021.

KRYSHTANOVYCH, M. et al. Pedagogical and Psychological Aspects of the Implementation of Model of the Value Attitude to Health. BRAIN. Broad Research in Artificial Intelligence and Neuroscience, Iași, v. 11, n. 2, suppl. 1, p. 127-138, 2020. DOI: https://doi.org/10.18662/brain/11.2Sup1/99

KULGANOV, V. A.; KUZMICHEVA, I. V. Formy i pričiny deviantnogo povedenija podrostkov [Forms and causes of deviant behavior of adolescents]. Psihologija 
Obrazovanija v Polikul'turnom Prostranstve [Psychology of Education in a Multicultural Space], v. 2, n. 3-4, p. 45-53, 2009.

NEVERKOVICH, S. D. et al. Students' Internet Addiction: Study and prevention. EURASIA Journal of Mathematics, Science and Technology Education, Yelets, v. 14, n. 4, p. 14831495, 2018. https://doi.org/10.29333/ejmste/83723

OBOLENSKAYA, A. G. et al. Adolescent deviations, phenomenon of cybervandalism. Types. Prevention. In: INTERNATIONAL FORUM ON TEACHER EDUCATION, 4., 2018, Kazan. Proceedings [...]. Detroit: The European Proceedings of Social and Behavioural Sciences, 2018. p. 283-294.

SHVEDCHIKOVA, Y. S.; BIKTAGIROVA, M. F. Sbornik metodičeskih materialov po organizacii profilaktičeskoj raboty na osnove rezul'tatov social'no-psihologičeskogo testirovanija [Collection of methodological materials on the organization of preventive work based on the results of socio-psychological testing]. Perm: Center of PsychologicalPedagogical, Medical and Social Aid, 2020. Available:

http://cppmsp59.ru/upload/iblock/ca0/ca0bc0285646cac8df09fff993b95ee0.pdf. Access: 8 Dec. 2021.

SLAVOVA, N. A.; CHVYAKIN, V. A. Moral Development in Structure of Legal and Cultural Organization of Adolescent Personality with Critical Social Deviations. Psychology and Law, Moscow, v. 9, n. 2, p. 264-275, 2019. DOI:

https://doi.org/10.17759/psylaw.2019090218

TINUNTSEVA, G. N. Deviant behavior in adolescence. Irkutsk: Workshop, 2013.

ZMANOVSKAYA, E. V. Deviantologiya. Psihologiya otklonyayuschegosya povedeniya [Deviantology: Psychology of deviant behavior]. Moscow: Academia, 2003.

\section{How to reference this article}

BEZUSOVA, T. A.; VATINA, E. V.; NARYKOVA, G. V.; MALTSEVA, N. V.; PETROVA, O. A. Psychological and pedagogical foundations of preventive work in educational institutions. Revista online de Política e Gestão Educacional, Araraquara, v. 25, n. 3, p. 24282442, Sep./Dec. 2021. e-ISSN: 1982-5587. DOI: https://doi.org/10.22633/rpge.v25i2.15922

Submitted: $25 / 09 / 2021$

Required revisions: $17 / 10 / 2021$

Approved: 19/11/2021

Published: 08/12/2021 